\title{
Securitisation in South Africa: 2000-2007
}

\author{
Z. Moyo and C. Firer* \\ Graduate School of Business, University of Cape Town, \\ Private Bag X3, Rondebosch 7701, Republic of South Africa \\ cfirer@gsb.uct.ac.za
}

Received March 2008

\begin{abstract}
This paper tracks the development of the securitisation market in South Africa since the first securitisation in 1989. It gives a chronological account of securitisation issuance activity on the Bond Exchange of South Africa and identifies factors that have led to the development of the market. It also records some of the topical issues market participants face.
\end{abstract}

Listing data from the Bond Exchange of South Africa was sorted and analysed. The views of market participants were captured through interviews and by attendance of the 2007 annual securitisation conference.

\begin{abstract}
The results show that the South African securitisation market has grown exponentially over the last seven years. Market participants expect this market to continue to grow, but at a slower pace, given the pressure that world credit markets are under as a result of the sub-prime crisis in the US. Market participants identified the constraints to growth as being insufficient capacity of local investors to take up the paper. From a supply point of view the South African banks have substantial securitisation capacity that is still untapped.
\end{abstract}

*To whom all correspondence should be addressed.

\section{Introduction}

Securitisation has its origins in banking and the innovation of banking products. Banks traditionally fund long dated assets (loans) with short dated liabilities (deposits). Bhattacharya and Thakor (1993) suggest that banking theory has largely become a maturity transformation debate where the fundamental question is whether the banks should fund their asset portfolios with deposits or by selling asset backed claims commonly known as securitization issues.

Whilst established markets such as the USA have used innovative tools such as securitisation since 1970, the first securitisation issue in South Africa was carried out in November 1989 by the United Building Society (now part of ABSA). This issue was based on ZAR 250 million of the bank's mortgage book (Saayman \& Styger, 2003, citing Faure, 1991). This was followed in 1991 with a private placing of instalment rental loans by Sasfin.

Financial innovation was slow in South Africa as businesses adjusted to the post-economic sanctions world of 1994. Research carried out shortly after the first two securitisation issues came to the market, pointed to a market that, though keen on securitisation, was not fully aware of the benefits (Tensfeldt, Firer \& Bendixen, 1993). The study revealed that there was an acceptance of securitisation as a financial engineering tool but the tentative conclusion reached was that it was still too complicated to be universally accepted within South Africa.

There was no further securitisation activity in South Africa until 1999 when the Retail Apparel Group securitised their debtors' book in a deal worth ZAR 600 million. Later that year Unibank securitised ZAR 430 million of its term loan book.

Securitisation activity in South Africa has been growing since 2000, initially at a slow pace but accelerating since 2004. The growth coincided with a protracted economic upswing and with concurrent growth in the overall corporate bond market. A growing economy has led to more demand for credit and the market has responded with financial innovation. Securitisation issues have grown from ZAR 482 million in 2000 to ZAR 25,2 billion in the first six months of 2007.

The objective of this paper is to present a picture of securitisation activity in the South African Bond Market over the period January 2000 to July 2007 and to review the unfolding of financial innovation in the asset-backed market in South Africa.

\section{Defining securitisation}

Securitisation is a financing process in which a corporate entity, usually a bank, moves assets to a bankruptcy remote special purpose vehicle created for the limited purpose of entering into the securitisation transaction. This special purpose vehicle then sells securities backed up by these loans in the open market. The process of converting assets into marketable securities is called securitisation (Mac Donald \& Koch, 2006).

Investors buy the repackaged assets in the form of securities or loans, which are collateralised (secured) on the 
underlying pool and its associated income stream. Securitisation thus converts illiquid assets into liquid assets and because the risk is lowered for lenders, they are willing to accept a lower interest rate. A credit derivative is generally also used to change the credit quality of the underlying portfolio so that it will be acceptable to the final investors.

The pool of loans being securitised may be home mortgages or commercial mortgages, motor vehicle loans or credit card receivables. The process of securitisation generally follows a similar pattern irrespective of the underlying loans that are being securitised. The mechanics of the transactions often differs, but underlying economics are the same. Figure 1 illustrates a typical securitisation transaction.

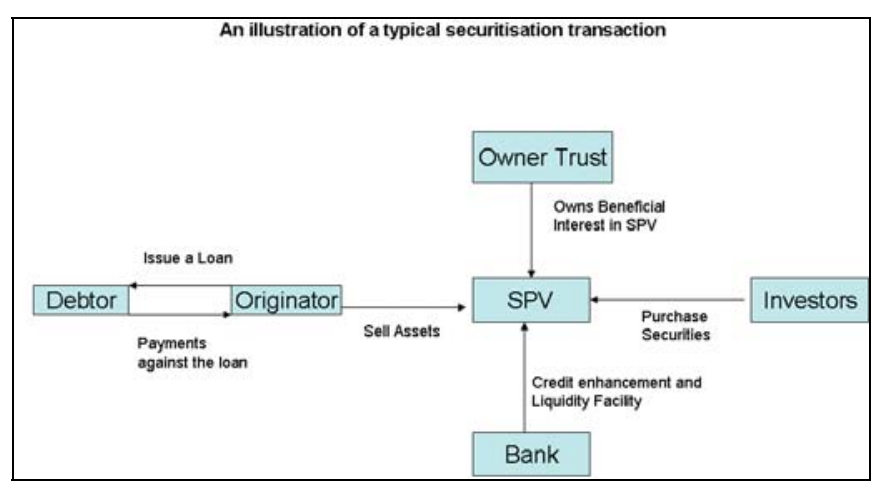

Figure 1: A typical securitisation transaction Source: Deloitte (2006).

Hess and Smith (1988) argue that securitisation has the effect of reducing transaction and information costs between borrowers and lenders, and that securitisation is a valuable hedging tool against interest rate uncertainty.

The growth of securitisation is related to the development of banking products. Banks use securitisation as means of matching on their balance sheets, interest rate sensitive liabilities with interest rate sensitive assets. For example, instead of using short-term deposits to fund a long-term loan, mortgage loan book securitisation allows a bank to pool the assets in the loan book, sell these off and use the proceeds to fund further lending.

All assets can be securitized so long as they are associated with a steady cash flow It is common in the real estate industry, where it is applied to pools of leased property, and in the lending industry, where it is applied to lenders' claims on mortgages, home equity loans, student loans and other debts. Securitisation transactions can be broadly grouped as follows (Deloitte, 2006):

- Residential Mortgage Backed Securities (RMBS) are a pool of assets consisting of residential mortgage loans.
- $\quad$ Asset Backed Securities (ABS) ${ }^{1}$ are a pool of assets consisting of credit card receivables, vehicle loans or leases, other type of consumer loan, equipment leases and trade receivables.

- Commercial Mortgage Backed Securities (CMBS) are a pool of assets consisting of commercial mortgages that may consist of a single property or a group of properties financed by a single borrower, or a pool of assets that combines numerous loans from different borrowers secured by diverse commercial properties.

- Collateralised Debt Obligations (CDOs) are a pool of assets such as commercial loans to corporations.

\section{South African securitisation studies}

Tensfeldt et al. (1993) found that securitisation activity was slow to start because senior bankers were not fully convinced that the benefits of securitisation outweighed the costs. In revisiting this question, Saayman and Styger (2003) contended that the poor liquidity of corporate bonds was a potential problem for investors and argued that the appetite for asset-backed paper by investors would be low as a result. Closely linked to liquidity in the corporate bond market was the tradability of securitisation instruments. There was no commitment from any of the banks to market securitisations issues, since it would cost a bank too much in terms of the capital charge to hold an inventory of assetbacked securities for market making purposes. They also attributed the slow growth in securitisation to a lack of confidence in rating agencies locally.

Another reason for the slow rate of securitisation suggested by both Tensfeldt et al. (1993) and by Saayman and Styger (2003) was the limited appreciation by local banks of the advantage to capital efficiency that securitisation brings. They both suggested that local banks had adequate amounts of capital and hence saw little need to use financial engineering tools, and felt that there was a general lack of knowledge of the full economic benefits of securitisation at the time.

Saayman (2003) examined the impact of securitisation on bank liquidity in South Africa to see if the liquidity of local banks could be improved through securitisation. This study was carried out after a series of insolvencies of smaller banks beginning in 1999, which saw banks such as New Republic Bank (1999), FBC Fidelity (1999), Regal Treasury Private Bank (2001) and Saambou Bank (2002) fail because of poor liquidity. Her conclusions were that the main risk facing South Africa's small banks was the lack of liquidity and that securitisation had the positive result of alleviating the liquidity problem provided it was done on a continuous basis.

Despite studies pointing to such benefits, a large-scale shift towards securitisation did not take place immediately. The bigger banks did not see the need to securitize as they had

${ }^{1}$ BESA makes a distinction between credit card backed securitisations CCBS and motor vehicle backed securitisations MVBS. 
adequate capital and were happy with the rate of growth of their assets. There was still scepticism around the risks of securitisation.

The rate at which banks securities their assets is largely dependent on demand for loans versus the amount banks have raised as deposits. Both Saayman (2003) and Rau (2004) noted that South African banks have a strong deposit base, suggesting that banks may not be under pressure to securitize their loan books as they are able to fund further loan issues through deposits. In other words, banks were not lending as widely as they were being funded. So structurally the South African banking market did not support securitisation, as deposits more than covered loans. This in part could explain the relatively slow start to securitisation in the years 1989 to 2000 .

The increase in regulatory capital requirements for banks to $10 \%$ by the Bank of International Settlements meant that the cost of holding credit on the balance sheet was set to increase. At that time South African banks were trying to follow international trends by focussing more on return on capital rather than the traditional growth in assets (Raine, 2000). This meant that banks needed to use their balance sheets more efficiently and this raised the need for better awareness of financial engineering tools available for securitisation.

Loan demand grew in line with the growth in the South African economy after 2000 and this increased the need for tools such as securitisation. Aspects of the South African market that supported financial intermediation include strong banking laws, an independent central bank whose independence is guaranteed by the constitution and comparatively deeper financial markets. These conditions have enabled securitisation to take off in South Africa.

The growth of the corporate bond market has also supported the growth of credit as an asset class. In 1990, Davey (1990) reported that the South African corporate bond market at the end of 1989 was very small at ZAR 2,4 billion. By July 2007 this market had grown to ZAR 242,2 billion.

\section{Objectives}

The objectives of this study are firstly to provide a chronological account of the growth in the securitisation market by examining the listing activity on the Bond Exchange of South Africa (BESA). The second objective is to categorise the securitisation issues that have taken place in the market, and to suggest reasons for the patterns found. The third is to highlight some of the current topical issues in the securitisation market and to indicate how they may be influencing the market.

\section{Methodology}

BESA publishes a list of bonds outstanding at the end of each month. The so-called "bond static" file, which contains this data, is publicly available. It was used as a basis for examining listing activity. Once the securitisation issues were identified by month from January 2000 to July 2007, they were then classified into different securitisation types, namely, Residential Mortgage Backed Securities (RMBS), Commercial Mortgage Backed Securities (CMBS), Credit Card Backed Securities (CCBS), Motor Vehicle Backed Securities (MVBS), Collateralised Debt Obligations (CDO) and Other Asset Backed Securities. The data was then analysed using simple descriptive statistics.

The key players in the South African securitisation market, are the five major banks, Rand Merchant Bank (acting on behalf of FirstRand Bank), Investec Bank, Standard Bank, ABSA Bank and Nedbank. After analysis of the secondary data, a number market participants in these banks were contacted via telephonic interviews and email communication. They were chosen on the basis of availability and personal contact. Their input was used to bring clarity and understanding about the relevant market issues that might not be obvious from a simple review of the issuance data. No structured questionnaire was sent out to the market participants, but the general line of questioning was as follows:

1. General market information post 2000 was gathered.

2. What were the key market drivers?

3. What were the key impediments to growth?

4. What opportunities exist in the market for asset backed paper?

5. What does the future for the South African securitisation market look like?

The final part of the qualitative data collection process was carried out during the $5^{\text {th }}$ Annual Securitisation Conference which was held in Cape Town on the $29^{\text {th }}$ and $30^{\text {th }}$ October 2007. There were 350 delegates, who fell into the following categories: investors (15\%), issuers (31\%), arrangers (27\%) and service providers (27\%). Most of them were direct market participants in the South African financial markets

Detailed notes were taken of the proceedings, which took the form of panel discussions by industry experts. In addition, in cases where clarification was needed, informal discussions were held with delegates.

\section{Results}

The value of listed securitisation issues over the period 2000 to 2007 is shown in Table 1 . It rose quite rapidly until 2003, declined in 2004 and then grew almost three fold in 2005 and continued on a high growth trajectory. The January through June 2007 figures suggest that the value of new shares in 2007 will surpass that of 2006. The listed debt market in South Africa grew by only $77 \%$ from 2000 to 2007, whereas securitisation growth far exceeded this figure. A brief discussion of the key features of each year's issues follows. 
Table 1: Value of new securitisation issues (Rm)

\begin{tabular}{c|c}
\hline Year & Value of New Securitisation Issues (Rm) \\
\hline 2000 & 482 \\
\hline 2001 & 1250 \\
\hline 2002 & 7680 \\
\hline 2003 & 9070 \\
\hline 2004 & 7095 \\
\hline 2005 & 21444 \\
\hline 2006 & 28394 \\
\hline $2007^{*}$ & 25232 \\
\hline
\end{tabular}

* First six months only

Kiwane, a Collateralised Debt Obligation and the first of its kind to be issued in South Africa was the only listed securitisation issue in 2000.

There was also only one securitisation listing, the Thekwini series issued by SA Homeloans. It was a Residential Mortgage Backed Security, the first with an issue size of over ZAR 1 billion.

In 2002 the securitisation market gathered momentum. The second Collateralised Debt Obligation was issued (the Fresco issue done by RMB on behalf of FirstRand Bank). The first credit card backed securitisation (On the Cards) was carried out by Edgars Store Limited. Other issues of significance were the Fintech receivables issue and the Procul issue, which was the first motor vehicle backed securitisation.

In 2003 ZAR 5 billion in motor vehicle backed securitisations took place. BMW Finance (SA) issued their first motor vehicle backed securitisation, the first by a nonbank issuer. ABSA entered the market with their first motor vehicle backed securitisation with the CAR series issue. Residential mortgage backed securitisations grew owing to the repeat issues of Thekwini (from SA Homeloans) and Private Mortgages (from Investec Bank).
Part of the slow down in issuance in 2004 may be attributed to market expectations that interest rates, after having declined significantly from the 2001/2002 highs, would decline further. As a result, corporations may have chosen to delay coming to the market in the hope of issuing bonds at more favourable interest rates. In 2004 the first commercial mortgage backed securitisation was issued by Pangbourne, iFour and ABSA bank.

The value of new securitisations issued in 2005 grew three fold from the previous year. Part of this growth may be the result of changing interest rate expectations; in 2004 interest rates were expected to continue falling, when this did not happen issues that had been in the pipeline were brought to market. New issuers in 2005 were Woolworths Limited with their credit card backed securitisation and Group Five Limited with their commercial mortgage backed securitisation. Issue sizes grew significantly in 2005.

2006 was a very active year for new securitisation issues especially by non-bank small issuers, for example Blue Diamond Investments, SA Earl and Freestone (Pty) Ltd. Motor vehicle backed securitisations exceeded residential mortgage backed securitisation, which had previously dominated new issues.

New issues came to the market at a brisk pace in 2007. By mid-year, the new issue figure had approached the 2006 total. Rising volumes of motor vehicle backed securitisations were observed.

\section{Classification of the securitisation issues}

A review of the securitisation issues in South Africa led to the identification of six broad classifications of asset-backed paper. The securitisation issues over the period 2000 to mid2007 are broken down into six categories in Table 2: Collateralised Debt Obligations, Residential Mortgage Backed Securities, Commercial Mortgage Backed Securities, Motor Vehicle Backed Securities, Credit Card Backed Securities, and Other Asset Backed Securities.

Table 2: Securitisation issuance by classification ( $R$ million)

\begin{tabular}{|c|c|c|c|c|c|c|}
\hline Year & CDOs & RMBS & CMBS & MVBS & CCBS & Other \\
\hline 2000 & 482 & - & - & - & - & - \\
\hline 2001 & - & 1250 & - & - & - & - \\
\hline 2002 & 1082 & 2055 & - & 1960 & 1930 & 653 \\
\hline 2003 & - & 3400 & - & 5000 & - & 670 \\
\hline 2004 & - & 2500 & 800 & 2400 & 895 & 500 \\
\hline 2005 & - & 10799 & 1575 & 4400 & 4670 & - \\
\hline 2006 & 198 & 11973 & 3122 & 12207 & 895 & - \\
\hline $2007 *$ & 191 & 10067 & 3031 & 10837 & 1015 & 91 \\
\hline Total issued & 1953 & 42044 & 8528 & 36804 & 9405 & 1914 \\
\hline
\end{tabular}

Source: BESA 
From Table 2 it is clear that the securitisation market was dominated by residential mortgage backed securities during the period 2001 to 2005. In the next two years, almost half of the new issues were motor vehicle backed securitisations.

Collateralised debt obligations appear to be least favoured of the asset-backed paper; with only two significant issues, the Kiwane issue in 2000 and the FRESCO issue in 2002, appearing. Commercial mortgage backed securities were slow to take off, the first such issue only taking place in 2004, and volumes have remained low when compared to that of residential mortgage backed securitisations.

Two non-bank issuers, Edgars Stores Limited and Woolworths Limited dominated the credit card securitisation market. A non-traditional issue that recently came to the market is the ZAR 91 million aircraft backed securitisation. Figure 2 is a graphical representation of the securitisation issues by classification.

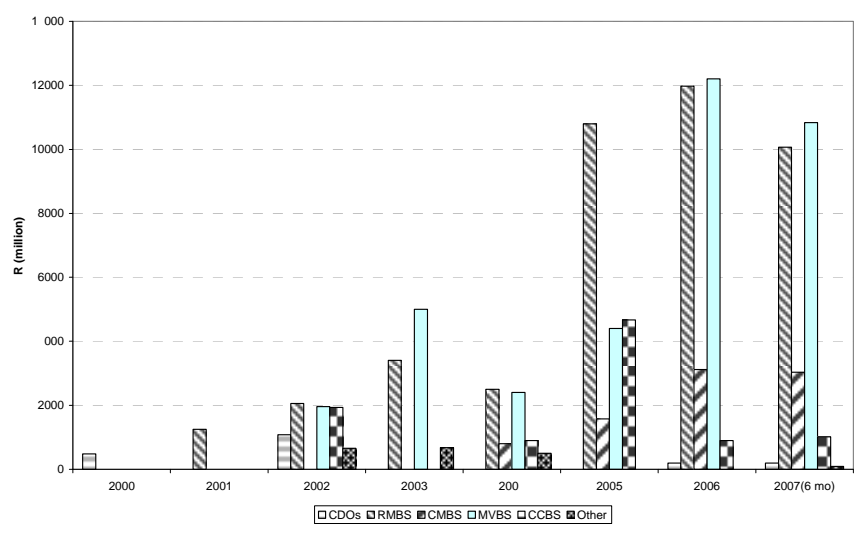

Figure 2: Securitisation issuance by classification

\section{Discussion}

\section{Local market saturation and offshore distribution}

Sixty nine percent of the delegates to the 2007 Securitisation Conference felt that the local investor market had not reached saturation point for securitisation paper. Despite this result market participants outside of the conference felt that there were limits to South African investor demand, since the potential investor base consists of only approximately twenty conduits, banks, fund managers and pension funds.

Analysts suggested that the demand from this investor base as well as mandate constraints for notes backed by existing South African assets was unlikely to continue to meet the current rate of increase in issue volumes and so they anticipated an excess supply.

Market players interviewed felt that excess capacity existed on the supply side, since South African banks have traditionally funded their lending on a short-term basis (deposits). Recently local banks have come under pressure from the Central Bank to improve their term funding, so securitisation activity from the supply side is likely to continue for sometime.

This situation was underscored by the fact that local issuers are starting to test the offshore market. For example, Rand Merchant Bank, acting with Morgan Stanley \& Co International Limited on behalf of Wesbank Limited, placed the Nitro 2 motor vehicle loans securitisation issue in September 2006, and in March 2007, Standard Bank acting with Royal Bank of Scotland Plc effected the Blue Granite 4 placement, a South African residential mortgage backed securitisation, both into the European market. Each issue was in excess of ZAR 4 billion, suggesting that the offshore market was able to take volumes which could be difficult to place locally.

According to conference panellists, typical buyers of South African securitisation paper offshore are US based mutual funds, real money funds and banks wanting to repackage the securities, this despite the local issues being placed in Europe.'

Since the US debt market was the biggest in the world, panellists felt that if South African securitisation issuers wished to establish a strong offshore presence, they should target the US market. Acceptance of South African assetbacked bonds in this market would lead to a boost in local reporting standards as a whole because of the stringency of the US securities laws and the rigour of the due diligence process.

\section{Drivers of widening credit spreads}

Generally non-bank issuers are much less price sensitive than banks, since banks have to take into account the full economic cost of a securitisation transaction which includes capital adequacy charges. A poll at the conference addressing the question: 'What in your opinion has been the main driver of widening credit spreads in the securitisation market?' produced the following responses:

Credit concerns $35 \%$

Competing supply

Interest rate outlook $23 \%$

Limited secondary market liquidity

$15 \%$

These results were surprising since, in the interviews with market participants who were bank issuers, widening spreads of securitisation issues were attributed to changes in the interest rate outlook and not to credit concerns. They suggested that in a high interest rate environment, loan delinquencies should increase and so the pricing of individual transactions should worsen with changes in the interest rate cycle.

Supporting the notion that poor pricing is the result of credit concerns would imply that banks are not managing credit risk correctly, so the likelihood of a bank issuer attributing poor pricing to credit issues is low. This point is underscored by the fact that when the sub prime crisis in the 
US began, bankers were reluctant to agree that the problem was credit related but rather pointed to the changes in interest rate cycle. The securitisation conference had a wider audience than bank issuers and perhaps offered a more balanced view.

\section{Local investor round table}

A round table of local investors at the conference expressed concern at their inability to assess pools of underlying assets adequately because of a lack of transparency. This posed challenges when assessing the risk profile of certain issues; investors felt that issuers could do more to help in this regard. Whilst transparency for non-bank issuers was not a problem, it was suggested that banks may be wary of disclosing propriety information about their clients.

It was also noted that secondary market liquidity of securitisation issues was virtually non existent, perhaps because banks were unwilling to make a market in securitisation issues due to expense.

A third issue that may be affecting securitisation issuance was the stellar performance of local equity market, breaching the historic 30000 level in 2007, and negatively affecting the holdings of fixed income securities.

Tensfeldt et al. (1993) found a general mistrust for rating agencies. Participants at the conference accepted that the work of rating agencies was very important to the growth securitisation market. However, the rating agencies present suggested that local banks were not providing them with enough loan information to calculate accurate default probabilities.

\section{Views of European investors}

The discussion at the conference about South African issues in the European market was dominated by events linked to the US sub prime crisis. Since the crisis began in August 2007, the issuing of asset-backed paper, particularly in emerging markets, had virtually come to a standstill. The European investors present preferred South Africa as an investment destination, but events in the US credit market precluded investment in any form of credit. Another reason why South African assets were favoured by the Europeans was that, in the emerging market universe, the relative liquidity of both the rand and the capital market (particularly for government bonds) was greater than for other emerging markets.

The outlook for South Africa's asset-backed market was positive and comments were made that quality of the underlying assets was good. Investors expressed confidence in the credit processes of South African banks and related securitisation issues. However in the context of a US credit market that was re-pricing, the opinion was that the issuing of South African securitisation paper in the European market would likely slow down until the credit markets' turmoil had dissipated.

\section{Commercial mortgage backed securities}

The issuing of commercial mortgage backed securities in South African has been slow to take off. This was a major discussion point in the conference. It was suggested that one reason for this is because the average loan to value ratios in South Africa are only about 50\%, whereas the ratios for residential mortgage backed securities are about $80 \%$. This makes commercial mortgage backed securities unattractive for bank issuers, as they seek gearing to obtain a desired level of return on equity. It explains why the commercial mortgage backed security market is dominated by non-bank issuers at present. Discussants suggested that commercial mortgage backed securitisations will give banks the opportunity to diversify their funding program, and perhaps this could stimulate the market in the future.

\section{Collateralised debt obligations}

The South African securitisation market has had three notable CDO transactions, the Kiwane issue in 2000, the FRESCO 1 issue in 2002 and the FRESCO2 in 2007. Four reasons were advanced at the conference for why this segment of the market may have been slow to start in South Africa.

Very few corporations are rated; this means that shadow ratings are applied. Thus investor information about the underlying loans is not very transparent leading to a reluctance to invest.

Secondly, the paucity of loan data from the banks means that rating agencies face a high degree of modelling complexity. Thirdly, there are no comparative benchmarks since the credit derivative market is very small in South Africa. Lessons from the US market are that collateralised debt obligations should be simple, transparent and have good quality of underlying assets. The fourth reason advanced was that local investors may not fully understand the products - hence their reluctance to invest in them.

Conference delegates felt that the CDO market was likely to grow in South Africa as banks try to take advantage of benefits such as the fact that the originator can use them as a credit risk management tool; they can be used to manage economic capital of a bank; and their use in liquidity risk management. For investors, benefits identified included the diversification benefit and the certainty of cash flows.

\section{Basel 2}

A session at the conference centred on the impact that Basel 2's risk weighting requirements would have on securitisation issue patterns. For example, the risk weighting on residential mortgage backed securities was 50\% whereas the risk weighting on motor vehicle backed securities was $100 \%$. So if a bank was faced with choosing which assets to securitize, from a regulatory capital saving point of view, it would be more effective to choose motor vehicle backed loans over residential mortgage backed paper. It was suggested that bank issuers would, in light of Basel 2, look 
at the extent to which there can be a capital saving before they issue securities.

\section{Future of the South African Securitisation Market}

Internationally, and especially in the US where the mortgage market is guaranteed by the Federal agencies, securitisation markets have been dominated by issues of residential mortgage backed securities. This is also true of the South African market, which has grown despite the lack of a government guarantee.

Motor vehicle backed securitisations have been the second most popular securitisation type. The local market is dominated by bank issuers (the sole automobile issuer is the BMW Finance (SA) Company), whereas elsewhere in the world motor vehicles loans are dominated by service providers linked to the automobile companies. Credit card backed securitisations in the South African market are the next most common securitisation type, and are dominated by two non-bank issuers; elsewhere in the world bank issuers dominate this market. Commercial mortgage backed securities have been identified as having good potential but to date issuance in the South African market has been disappointing. The collateralised debt obligation market in South Africa has but one current issuer; whereas in the US this market is quite big and is actively traded.

When comparing the structure of the South African securitisation market to that of more established markets, it appears that the strongest growth prospects lie in the commercial mortgage backed securities and the collateralised debt obligation market.

Factors which conference delegates felt would slow down securitisation issuance included the current turmoil in the world credit market and the introduction of the National Credit Act of 2007 (NCA), which was likely to slow down the rate at which banks lend to their customers due to the enhanced due diligence requirements. Although the NCA would lead to an improvement in the quality of loans given by credit granting institutions, it could slow down the rate of credit extension to the public. This will put less funding pressure on the banks, resulting in a slowdown the rate of securitisation.

Conference delegates felt that individual securitisation classes in the South African market may be affected in the following ways. When credit markets find favour again, expectations are that the residential mortgage market, which has experienced strong growth, will grow at slower pace than previously because under Basel 2 the regulatory capital saving may be too small to justify securitising the mortgage book.

The rate of motor vehicle securitisation is expected to continue to grow at a fast pace. The capital risk weighting under Basel 2 of automobile loans is high so there would be some regulatory arbitrage for banks to securitize their automobile loans.

Credit card backed securitisations are also likely to grow at a fast pace if banks were to enter this market.
Commercial mortgage backed securitisations have been slow to start in South Africa. Market participants believe that the clear benefits of commercial mortgage backed securitisation for a bank issuer remain small, though this may change under Basel 2. However, there is still scope for non-bank issuers to get involved in this market.

The collateralised debt obligation market remains in a startup phase; in light of developments with the pending adoption of Basel 2, and taking their cue from the developed markets, market participants believe that this market has potential to grow to be very dominant in the asset-backed space.

The South African securitisation market appears to have no supply constraints. South African banks have substantial spare capacity to securities their asset. Therefore the limit to growth in the future of the securitisation market will probably come from a lack of demand by South African investors. Market participants believe local investors' ability to take asset-backed paper has to date been constrained by fairly conservative investment mandates; these mandate restrictions may need be relaxed in the future to provide further support to the securitisation market.

\section{Conclusion}

The objectives of this paper were to characterise listed securitisation issue activity in South Africa during the years 2000 to 2007. This involved analysis of listing data from the Bond Exchange of South Africa. In addition open-ended interviews were carried out with securitisation market participants to determine their views on the current state of the market and its growth potential. Finally the $5^{\text {th }}$ Annual Securitisation Conference was attended in order to record the opinions of the market experts present at the conference. The listed securitisation market in South Africa has grown strongly since the year 2000. The total annual issuance in 2000 was ZAR 482 million and in the first 7 months of 2007 this figure was ZAR 25,2 billion.

The future of the South African securitisation market will be depend on future demand for asset-backed paper. From a supply point of view the market is nowhere near capacity. Local banks have in some cases not even begun to securitize their loan books to the extent that loans are securitised in more mature markets. The introduction of Basel 2 in January 2008 is likely to lend further support to the securitisation market as banks will need to manage their capital better.

The investor base in South Africa remains the challenge to growth in the securitisation market. Contrasting the narrow investor base with potential supply, market analysts believe that South African investors may not be able to take up the supply. This point is underscored by local issuers starting to place paper in the European market. Since the sub-prime crisis in August 2007 however placing of local asset-backed paper has been suspended due to lack of demand. The ongoing re-pricing of credit risk in the international markets has had the effect of slowing down issuance of credit worldwide. This may well provide a brake, in the short term, on the use of the offshore markets by securitisation issuers. 


\section{Acknowledgements}

The authors would like to thank all those who gave of their time to provide information, assistance and advice during the study. A special thanks to Gillian Raine at Rand Merchant Bank and to Mark Van Wyk at Mettle.

\section{References}

Bhattacharya, S. \& Thakor, A. 1993. 'Contemporary banking theory', Journal of Financial Intermediation, 3: 250 .

Davey, P.W. 1990. 'Role of corporate bonds in South Africa', Witwatersrand Business School, Wits University MBA Research Report.

Deloitte. 2006. 'Simply securitisation'. Connecting the Process Series 1/2006. Johannesburg: Deloitte Touche Tohmatsu,

Hess, A. \& Smith, C. 1988. 'Elements of mortgage securitisation', Journal of Real Estate Finance and Economics, 1(4): 331-346.

MacDonald, S.S. \& Koch, T, 2006. Management of Banking, 6th Edition, Mason, Ohio USA: Thomson South Western.

Raine, G. 2000. 'Securitisation: Recent initiatives by Rand Merchant Bank,' SA Treasurer, 15: 26-28.

Rau, N. 2004. 'Financial intermediation and access to finance in African countries south of the Sahara'. South African Reserve Bank, Forum Paper, African Development and Poverty: The Macro Linkage, Oct.

Saayman, A. 2003. 'Securitisation and bank liquidity in South Africa', Working Paper, Potchefstroom University.

Saayman, A. \& Styger, P, 2003. 'Securitisation in South Africa: Historic deficiencies and future outlook,' Working Paper, Potchefstroom University.

Tensfeldt, G., Firer, C. \& Bendixen, M.T. 1993. 'Bankers view on securitisation in South Africa', Investment Analyst Journal, 37: 9-24. 